\title{
Mouse Histiocytic and Dendritic Cell Neoplasm
}

National Cancer Institute

\section{Source}

National Cancer Institute. Mouse Histiocytic and Dendritic Cell Neoplasm. NCI

Thesaurus. Code C134996.

A tumor arising from histiocytes and dendritic cells and occurring in a mouse. 